\title{
Analysis of Creative Thinking Abilities of Prospective Mathematics Teachers in Solving and Posing Quadrilateral Open- ended Problems
}

\author{
Jovitha Indah Gisbtarani \\ Sanata Dharma University, Email: jovitha.indah07@gmail.com \\ Veronika Fitri Rianasari \\ Sanata Dharma Univeristy, Email; veronikafitri@usd.ac.id
}

\begin{abstract}
Prospective teachers are required to develop their creative thinking abilities. The creative thinking abilities can help prospective teachers in designing the learning process, one of which is in designing non-routine problems as an evaluation of learning. This study aims to describe the creative thinking abilities of six sixth-semester students of Mathematics Education at Sanata Dharma University in solving and posing open-ended problems on the topic of quadrilateral. Data collection methods used are written tests to solve and pose openended problems and interviews. Data analysis adopted the framework of qualitative data analysis namely data reduction, data display, and conclusion drawing. The results showed that (1) the students' creative thinking abilities in solving open-ended quadrilateral problems were categorized into four categories namely very poor ( 1 student), poor ( 3 students), fair (2 students) and good (1 student), (2) the students' creative thinking abilities in posing openended quadrilateral problems were categorized into three categories of creative thinking abilities namely very poor ( 2 students), poor ( 1 student) and very good (3 students).

Keywords: Creative Thinking Ability, Solving Open-ended Problems, Posing Open-ended Problems, Quadrilateral
\end{abstract}

\begin{abstract}
ABSTRAK
Calon guru harus mengembangkan kemampuan berpikir kreatif mereka. Kemampuan berpikir kreatif tersebut dapat membantu calon guru dalam merancang proses pembelajaran, salah satunya dalam merancang masalah tidak rutin sebagai bahan evaluasi hasil belajar. Penelitian ini bertujuan untuk mendeskripsikan kemampuan berpikir kreatif enam mahasiswa semester VI Pendidikan Matematika Universitas Sanata Dharma dalam menyelesaikan dan merancang soal open-ended pokok bahasan segiempat. Metode pengumpulan data yang digunakan adalah tes menyelesaikan soal open-ended, tes merancang soal open-ended, dan wawancara. Analisis data menggunakan kerangka analisis data kualitatif yaitu reduksi data, penyajian data, dan penarikan kesimpulan. Hasil penelitian menunjukkan bahwa, (1) kemampuan berpikir kreatif mahasiswa dalam menyelesaikan soal open-ended segiempat dikategorikan ke dalam empat kategori kemampuan berpikir kreatif yaitu sangat kurang kreatif (1 mahasiswa), kurang kreatif (3 mahasiswa), cukup kreatif (2 mahasiswa) dan kreatif (1 mahasiswa), (2) kemampuan berpikir kreatif mahasiswa dalam merancang soal open-ended segiempat dikategorikan ke dalam tiga kategori kemampuan berpikir kreatif yaitu sangat kurang kreatif (2 mahasiswa), kurang kreatif (1 mahasiswa) dan sangat kreatif (3 mahasiswa).

Kata kunci: Kemampuan Berpikir Kreatif, Menyelesaikan Soal Open-ended, Merancang Soal Open-ended, Segiempat.
\end{abstract}




\section{INTRODUCTION}

Creative thinking is one of the 21 st century skills that is needed so that someone will be ready to cope with the demand of modern life (Ibrahim \& Widodo, 2020). Creative thinking includes the thinking process to create, discover, imagine, predict, design, propose alternatives, create and produce something (Thomas, Thorne \& Small, 2000; Siswono, 2016). Silver (1997) explained that the assessment of creative thinking of children and also adult can use The Torrance Test of Creative Thinking (TTCT). The three main abilities assessed in creativity using TTCT are fluency, flexibility, and novelty. Table 1 is an explanation of the links between the criteria of creative thinking in problem solving and problem solving.

Table 1. Relation between the Criteria of Creative Thinking in Problem Solving and Problem Posing

\begin{tabular}{cll}
\hline Criteria & \multicolumn{1}{c}{ Problem Solving } & \multicolumn{1}{c}{ Problem Posing } \\
\hline Fluency & $\begin{array}{l}\text { Students explore open-ended } \\
\text { problems having many } \\
\text { interpretations, solution methods, or } \\
\text { answers. }\end{array}$ & $\begin{array}{l}\text { Students create many problems to be } \\
\text { solved. } \\
\text { Students share their posed problems. }\end{array}$ \\
Flexibility & $\begin{array}{l}\text { Students solve using more than one } \\
\text { strategies. }\end{array}$ & $\begin{array}{l}\text { Students pose problems that can be } \\
\text { solved using different strategies. }\end{array}$ \\
& $\begin{array}{l}\text { Students discuss several solution } \\
\text { methods. }\end{array}$ & $\begin{array}{l}\text { Students use "what if not" approach to } \\
\text { pose problems. }\end{array}$ \\
Novelty & $\begin{array}{l}\text { Students examine several solution } \\
\text { methods then generate another new } \\
\text { solution methods. }\end{array}$ & $\begin{array}{l}\text { Students examine several posed } \\
\text { problems then pose a different new } \\
\text { problem. }\end{array}$ \\
\hline
\end{tabular}

Furthermore, Siswono (2007) explained indicators of creativity which refers to problem solving and problem posing. Table 2 is an explanation for these indicators.

Table 2. Indicators of Creativity in Problem Posing and Problem Solving

\begin{tabular}{lll}
\hline Criteria & Problem Solving & Problem Posing \\
\hline Fluency & $\begin{array}{l}\text { Fluency in problem solving refers to the } \\
\text { ability of students to provide correct } \\
\text { answers. }\end{array}$ & $\begin{array}{l}\text { Fluency in problem posing refers to the } \\
\text { ability of students to pose problems } \\
\text { along with the several solutions that are } \\
\text { correct. }\end{array}$ \\
Flexibility & $\begin{array}{l}\text { Flexibility in problem solving refers to the } \\
\text { ability of students to solve problems in a } \\
\text { variety of different ways } \\
\text { Novelty in problem solving refers to the } \\
\text { ability of students to give solution method } \\
\text { that is unordinary done by students at } \\
\text { this level of knowledge }\end{array}$ & $\begin{array}{l}\text { Flexibility in problem posing refers to } \\
\text { the ability of students to pose problems } \\
\text { that have different solution methods. } \\
\text { Novelty in problem posing refers to the } \\
\text { ability of students to pose a problem } \\
\text { that is different from the problem } \\
\text { previously posed. }\end{array}$ \\
\hline
\end{tabular}

According to Schoevers et al (2019), to develop students' creativity is to create a learning environment that provides opportunities for students to express their ideas. This can be realized if teachers is also open-minded to develop their creative thinking skills. The provision of a teacher's creative thinking ability in designing learning that fosters students' creative thinking abilities should be prepared since they are in teacher education. One such activities that can develop prospective teachers' creative thinking abilities are posing and solving non-routine mathematics problems. In solving non-routine problems, students will enter into a situation of uncertainty and uncertainty that can be a catalyst for creative thinking and action (Beghetto, 2017). 
Non-routine tasks aimed to measure the creative thinking in mathematics must fulfill the following characteristics: the tasks are in the form of problem solving and problem posing and also divergent in answers and solutions, so that the criteria for flexibility, novelty and fluency emerge (Silver, 1997). In this study, the authors used non-routine problems that were open-ended because open-ended problems could provide students with a rich experience in interpreting problems and also allowed students to produce various solution methods (Silver, 1994).

In mathematics education, a number of studies have discussed the ability of prospective teacher students in solving or posing open-ended questions (As'ari, Mahmudi \& Nuerlaelah, 2017; Bragg \& Nicol, 2008; Crespo, 2003; Demir \& Sahin, 2014). Research conducted by Bragg \& Nicol (2008) and Crespo (2003) focus on the experiences of prospective teacher students in designing open-ended mathematical problems, while research conducted by As'ari, Mahmudi \& Nuerlaelah (2017) and Demir \& Sahin (2014) focuses on the ability of prospective teacher students to solve open-ended questions. As far as the authors are aware, there are few studies that discuss the creative thinking abilities of prospective mathematics teacher students in solving and also designing open-ended questions. Therefore, in this study, the authors analyze the creative thinking abilities of prospective mathematics teacher students both in solving and posing open-ended problems.

In particular, the domain that is focused on in this study is geometry with the topic of quadrilateral. This topic was chosen with two considerations. First, geometry is a domain in mathematics that is rich in exploration of open-ended problems. Second, based on the results of TIMSS 2011, geometry is one of the mathematical domain that Indonesian students are less familiar with. By providing learning experience for prospective mathematics teachers to explore open-ended problems, it is expected that this experience will strengthen their pedagogical and content knowledge, especially on the topic of geometry.

\section{METHOD}

This research is a descriptive study with a qualitative approach since this study aims to describe the level of students' creative thinking abilities in solving and designing open-ended questions on quadrilateral subject matter. Students' creative thinking abilities will be analyzed based on each of the criteria, namely fluency, flexibility and novelty. Each criterion will be given a score of 0,1,2 or 3 according to the answer given. The assessment for each of the criteria for creative thinking is the result of adaptation of the theory of Cooney and Bosch (Moma, 2015). Furthermore, the respective scores obtained by the subject in solving and posing quadrilateral open-ended problems will be categorized based on the creative thinking category according to Oemar (2001) (See Table 3).

\begin{tabular}{cc} 
Table 3. Category of Creative Thinking Ability \\
\hline Interval & Category \\
\hline $85-100$ & Very Good \\
$70-84$ & Good \\
$55-69$ & Fair \\
$40-54$ & Poor \\
$0-39$ & Very Poor \\
\hline
\end{tabular}


This research was conducted at Sanata Dharma University Yogyakarta, Indonesia. The subjects in this study were 6 prospective mathematics teachers of the sixth semester undertaking micro teaching course at Department of Mathematics Education. They were selected from 16 students in one class of micro teaching course. The selection of the 6 subjects was based on the results of preliminary test in solving quadrilateral open-ended problems. Each test result category (high, medium, low) was represented by 2 students.

The data collection method employed in this study are written test for solving open-ended problems, written test for designing or posing open-ended problems, and interview. In addition, to prepare students to understand what is meant by open-ended problems, the author also designed a handout that discuss about open-ended problem. The handout was administered to the prospective teachers before the data collection was carried out. The first author also assisted students in exploring the handout.

The research instrument used in this study consisted of the main instrument, namely the authors herself and three supporting instruments consisting of written tests, guidelines for posing open-ended problems, and interview guidelines. The data gathered in this study were analyzed using the analysis model from Miles \& Huberman (1994), namely data reduction, data presentation and conclusion drawing.

The validation employed in this research were content validation and triangulation. To ensure the content validation, this study employed expert judgment by asking for the opinion of several experts regarding the suitability of the content of the three supporting instruments. According to Sugiyono (2010), triangulation in credibility testing is defined as checking data from several sources, techniques and times. This research employed source triangulation. Source triangulation is used to test the credibility of the data by verifying data gathered from different sources (Sugiyono, 2010). The authors compared the data obtained from solving the open-ended problems with the results of the interview, and also compared the data obtained from posing open-ended problems with the results of the interview.

The research procedure was divided into three stages, namely the preparation stage, the implementation stage and the data analysis stage. In preparatory stage, the authors were contact with the prospective teachers, designing the research instrument, and ensuring the validity of the instrument. In the implementation stage, the authors were selecting the research subjects, administering the written test of solving open-ended problems, and conducting interview regarding the problem solving. Before the subjects were asked to pose open-ended questions, the first author carried out learning activities to discuss the handout that explains about the characteristics of openended problems. After that, the prospective teachers were asked to pose open-ended problem on the topic of quadrilateral and then they were interviewed to examine their creative thinking abilities in designing open-ended problems. After the completion of data gathering, the data analysis stage was carried out. 


\section{RESULTS AND DISCUSSION}

In this section, the result will be divided into two main parts. In the first section, the authors discuss the result regarding prospective teachers' creative thinking abilities in solving quadrilateral open-ended problem. In the second section, the authors discuss the result regarding prospective teachers' creative thinking abilities in posing quadrilateral open-ended problem.

Prospective teachers' creative thinking abilities in solving open-ended problems

Based on the written test on solving quadrilateral open-ended problems and the interview, the category of the six prospective mathematics teachers' creative thinking abilities is summarized in the table 4 as follows.

Table 4. Category of Prospective Teachers' Creative Thinking Abilities in Solving Quadrilateral Open-ended Problems

\begin{tabular}{ccc}
\hline Subjects & Score & Category \\
\hline S1 & 41 & Poor \\
S3 & 28 & Very Poor \\
S6 & 50 & Poor \\
S10 & 57 & Fair \\
S15 & 43 & Poor \\
S16 & 70 & Good \\
\hline
\end{tabular}

The description of the prospective teachers' creative thinking ability is explained based on the categories they have in solving open-ended problems in the topic of quadrilateral.

a. The description of the prospective teachers' creative thinking abilities from the very poor category in solving quadrilateral open-ended problems

The subject belongs to the very poor category is S3. The prospective teacher in this category has not been able to meet the three criteria of creative thinking abilities, namely fluency, flexibility and novelty.

S3 was able to provide one solution to the three open-ended problems (problems no 2, 3, and 4), but S3 was unable to provide different solution methods. This shows that the subject was less fluent in solving the open-ended problems and the subject was not flexible in providing various solution methods. Then for open-ended problems with open solutions and final answers (problems no 1 and 5), the subject cannot provide the answers. The following is the problem number 5 (see Figure 1). 
5. Soal adaptasi dari "Oil Spill" OECD'S PISA Assessment 2012.

Pada 21 Agustus 2009 pukul 04.30 WIB, terjadi kebocoran ladang minyak

dan gas di lepas pantai Laut Timor. Kebocoran itu menyebabkan minyak menyebar ke laut dan membentuk suatu area. Di siang hari, kebocoran tersebut sudah diperbaiki dan area genangan minyak yang terbentuk sangat luas. Genangan minyak tersebut membentuk area seperti pada gambar berikut ini:

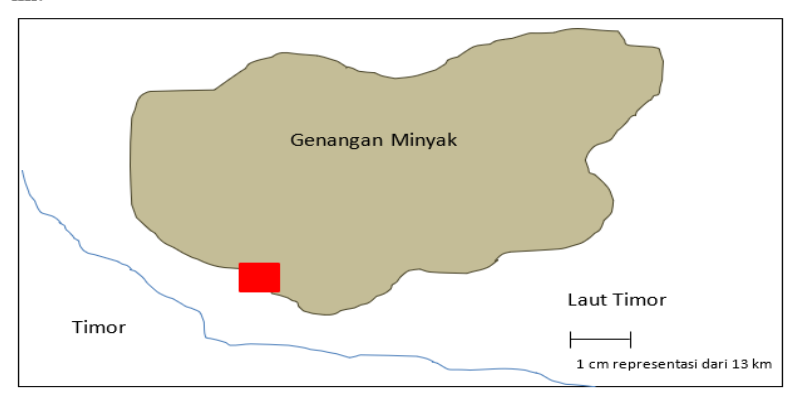

Pihak Kementerian Kelautan dan Perikanan ingin melakukan pendataan mengenai peristiwa tersebut, salah satunya mendata perkiraan luas area genangan minyak. Jika anda adalah orang yang ditunjuk oleh kementerian untuk melakukan tugas tersebut, bagaimana cara anda mengetahui perkiraan luas area genangan minyak tersebut (berdasarkan gambar yang diberikan)? Jelaskan cara anda!

Figure 1. Open-ended problem No 5

In solving problem number 5 which assess prospective teachers' ability in designing a certain solution to a problem situated in real world context, the subject did not provide the answer and the subject did not provide a detailed explanation when she was interviewed. The subject gave the following comments for problem number 5 during the interview:

$P \quad:$ What do you think about number 5 ?

S3 : I don't understand, because in my opinion there are no pictures and no figures for the calculations and nothing is known.

$P \quad:$ What exactly is it that makes you don't understand?

S3 : How to find out the approximate area, whereas if the picture is just like this what formula can be used

This results showed that the subject was les fluent in providing correct answers, not flexible in giving various solution methods and unable to come up with a new or unique solution. This description supports the results of the analysis of the scores obtained by S3 which states that the creative thinking abilities of the subject was very poor.

b. The description of the prospective teachers' creative thinking abilities from the poor category in solving quadrilateral open-ended problems

The subjects belong to the poor category are S1, S6, and S15. The prospective teachers in this category have been able to meet one of the three criteria of creative thinking abilities.

S1, S6 and S15 were able to provide solutions to the open-ended problems with open solutions (problem number 2, 3 and 4), but they were only be able to solve the problems with one correct and complete answer. This shows that the subject was not flexible in solving these open-ended problems. For open-ended problems with open solutions and final answers (problem number 1 and 5), the subjects were not able to answer it properly. Moreover, their answers did not show the novelty criteria. They were unable to provide the unordinary or unique solutions to solve the problems. Based 
on the explanation, it can be concluded that the creative thinking abilities of these subjects were poor since they cannot meet the criteria of fluency and novelty in solving open-ended problems.

c. The description of the prospective teachers' creative thinking abilities from the fair category in solving quadrilateral open-ended problems

The subject belongs to the poor category is $\mathbf{S 1 0}$. The prospective teacher in this category has been able to meet one of the three criteria of creative thinking abilities and has shown some efforts to show the other criteria.

Based on the written test and interview, the subject was able to meet the criteria for fluency in solving all open-ended problems, but the subject has not been able to optimally think flexibly to provide several correct solution methods to all of the open-ended problems. For problem number 5 which has openness in the way of completion and the final answer, the subject has tried to answer using two solution methods but then S10 failed to provide the correct answer (see Figure 2).

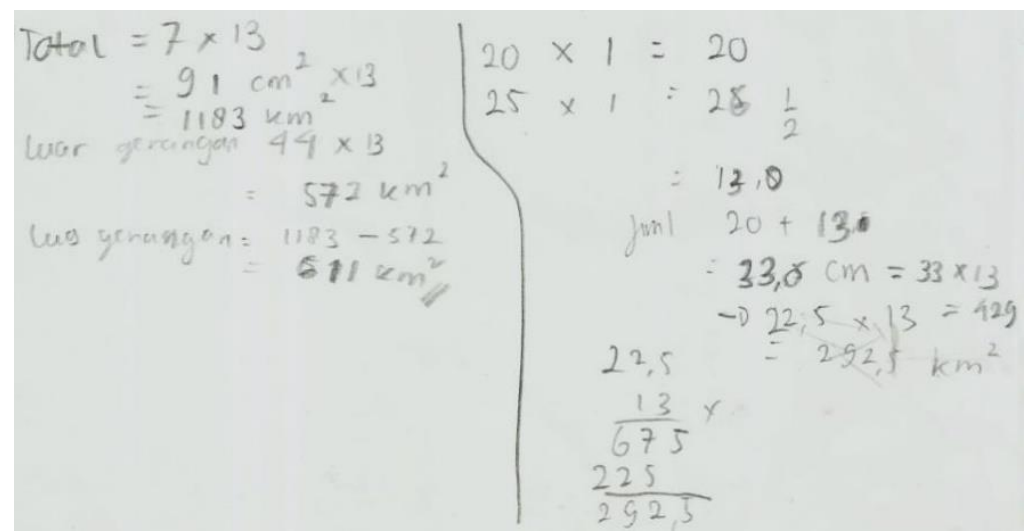

Figure 2. Solutions of problem no 5 given by S10

Furthermore, S10 also provided various solution methods for problems with openness in how to solve them (problems number 2, 3 and 4), but S10 failed to finish the alternative solutions she made. Based on the written test, the subject also was not able to provide new or unique solution methods to all the problems.

d. The description of the prospective teachers' creative thinking abilities from the good category in solving quadrilateral open-ended problems

The subject belongs to the poor category is S16. The prospective teacher in this category has been able to meet two of the three criteria of creative thinking abilities and has shown some efforts to show the other criteria. The works of S16 showed that the subject was able to meet the criteria for flexibility and fluency in solving all open-ended problems and the subject had shown some effort to show the novelty in two problems. In providing solutions to open-ended problem number 5 which has openness in the way of solving and the final answers, the subject had shown the flexibility by providing various solution methods (see Figure 3). 
Jika melihat darr' gumbar yg suya kevalion kemarin, ferelapat 22 totuk utuh. Juali inasnya misal:

$22 \times 13=206$

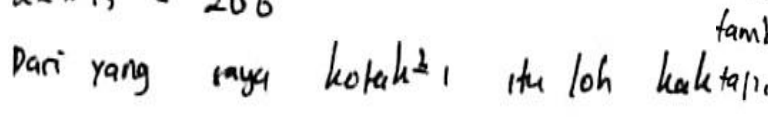

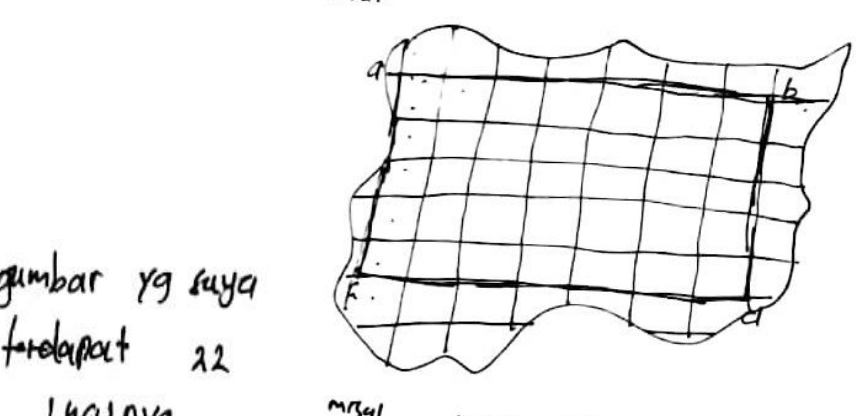
22

Nah itu saya hitary dulle be pemudicin numang Abcol, tambah persegr? larn diluar persegr bar di

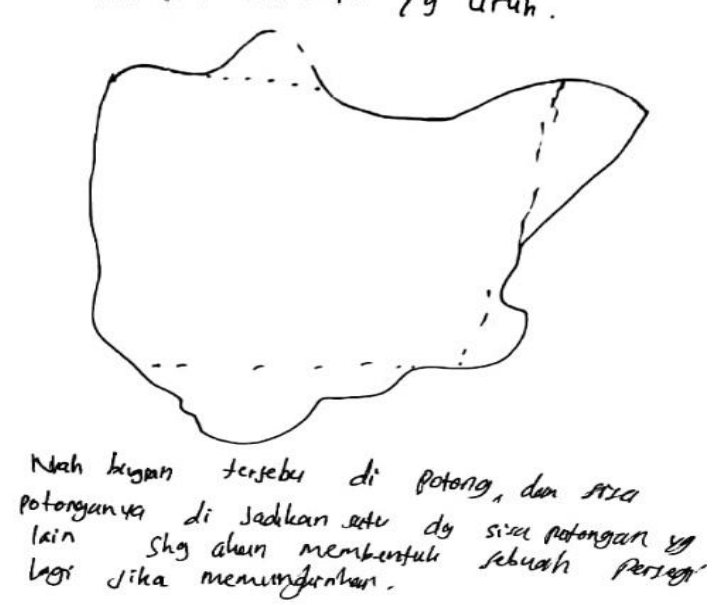

Figure 3. Solutions of problem no 5 given by S16

Furthermore, the subject was flexible in providing various solution methods for problems with openness in how to solve them (problem number 2, 3 and 4), and the subject was also fluent in giving correct answers to almost all of the problems. However, the subject had shown some efforts to provide different or unique solution methods to two of the problems even though the efforts did not help to arrive to the correct final answers.

Prospective teachers' creative thinking abilities in posing open-ended problems

Based on the written test on posing quadrilateral open-ended problems and the interview, the category of the six prospective mathematics teachers' creative thinking abilities is summarized in the table 5 as follows.

Tabel 5. Category of Prospective Teachers' Creative Thinking Abilities in Posing Quadrilateral Open-ended Problems

\begin{tabular}{ccc}
\hline Subject & Score & Category \\
\hline S1 & 89 & Very Good \\
S3 & 0 & Very Poor \\
S6 & 0 & Very Poor \\
S10 & 100 & Very Good \\
S15 & 44 & Poor \\
S16 & 89 & Very Good \\
\hline
\end{tabular}


The description of the prospective teachers' creative thinking ability is explained based on the categories they have in posing open-ended problems in the topic of quadrilateral.

a. The description of the prospective teachers' creative thinking abilities from the very poor category in posing quadrilateral open-ended problems

The subject belongs to the very poor category are S3 and S6. The prospective teacher in this category were unable to meet the three criteria for creative thinking, namely fluency, flexibility and novelty. This is because the subject is unable to design open-ended questions. The results of the analysis of the characteristics of the open-ended questions indicate that the three questions designed by the subject are not open-ended problems. Because of this explanation, it is not possible to analyze the subject's creative thinking ability in posing open-ended problems.

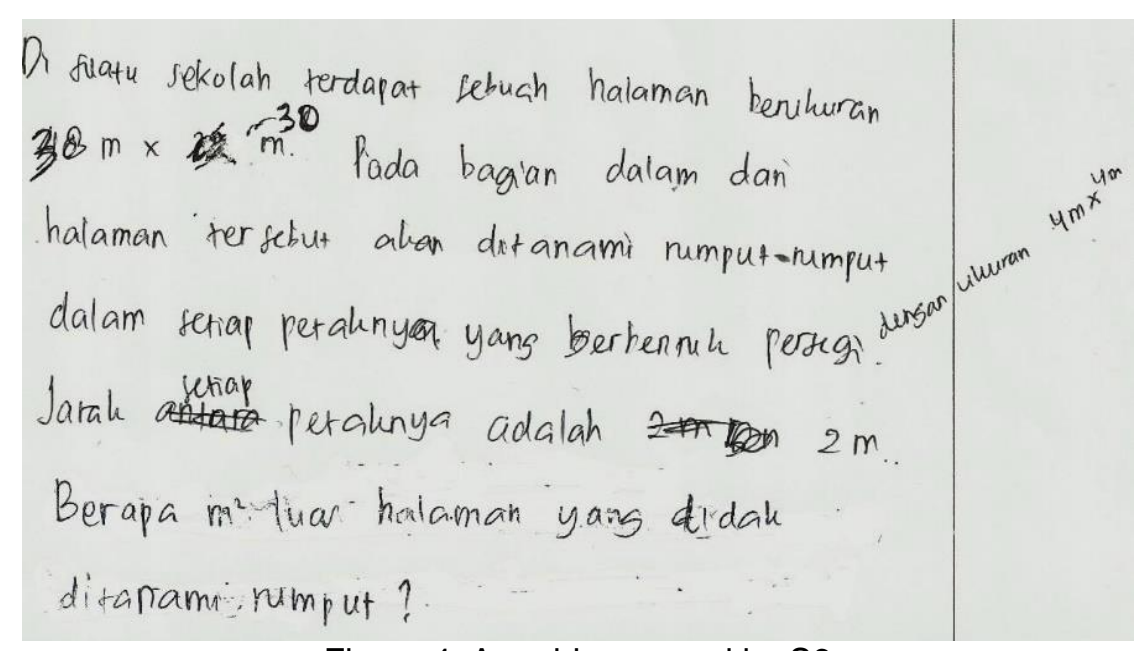

Figure 4. A problem posed by S6

However, S3 and S6 have actually been fluent in designing problems that are not open-ended. One of the questions made by the subject is a quadrilateral problem that is situated in real world context (see Figure 4). Then the subject has also been able to provide more than one solution for these problems, this shows that the subject is flexible in providing various correct solutions (see Figure 5). 


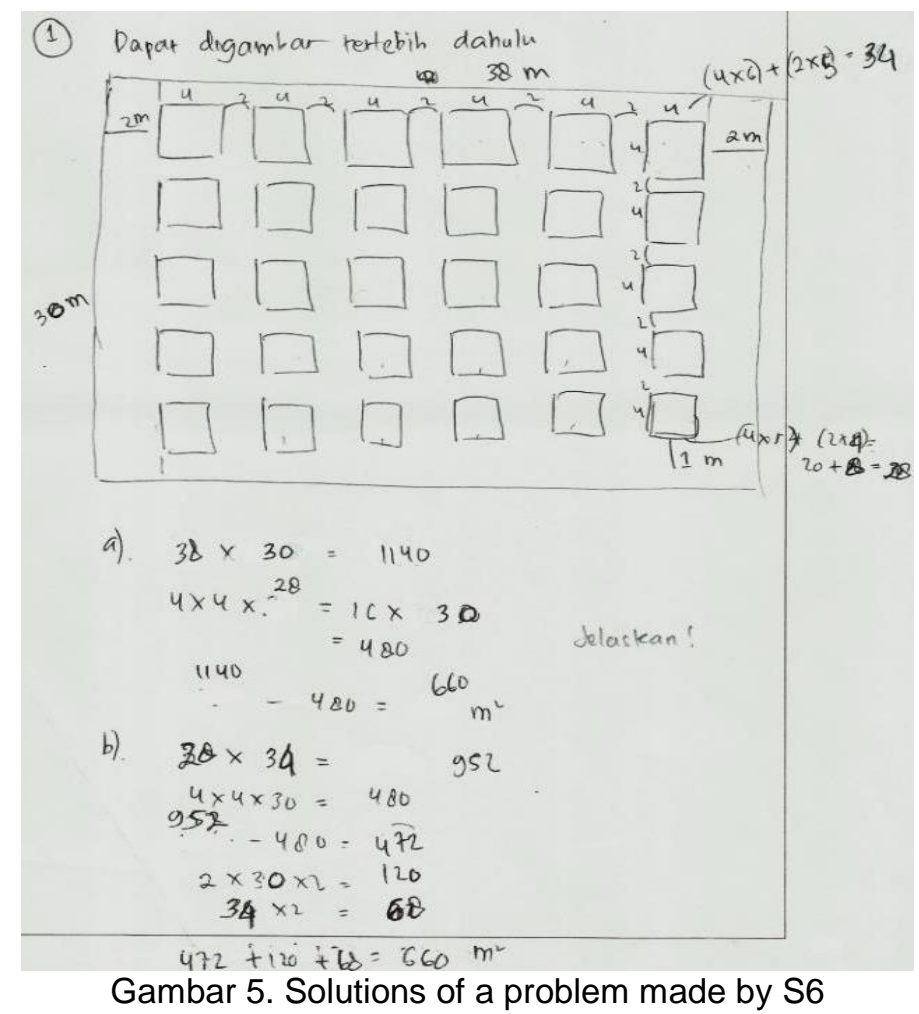

b. The description of the prospective teachers' creative thinking abilities from the poor category in posing quadrilateral open-ended problems

The subject belongs to the poor category is $\mathrm{S} 5$. The prospective teacher in this category gave some efforts to show the criteria of flexibility and fluency even though the results are less effective. Based on the analysis of the written work and interview, the subjects was only able to pose one openended problem. The novelty criterion cannot be achieved by the subject because the context and the main ideas of the problem posed by $\mathrm{S} 5$ are commonly used in mathematics textbook.

The quadrilateral open-ended problem designed by S5 is an open-ended problem that has open-ended final answer. The problem posed was not situated in real-life context (see Figure 6).

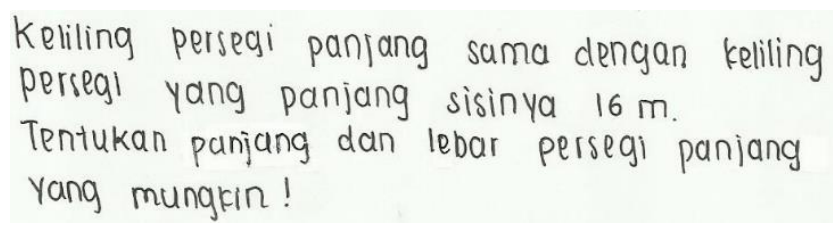

Figure 6. Open-ended problem posed by $\mathrm{S} 15$

c. The description of the prospective teachers' creative thinking abilities from the very good category in posing quadrilateral open-ended problems

The subject belongs to the poor category are S1, S10, and S16. The prospective teacher in this category have been able to meet the three criteria for creative thinking, namely fluency, flexibility and novelty.

Subjects in the very creative category have been able to meet the three criteria for creative thinking, namely fluency, flexibility and novelty. The subject were able to design more than one 
complete quadrilateral open-ended problems, provide more than one correct solutions, build pose problem using their own ideas.

The subjects were able to design problems with openness in how to solve them and openness in final answers. Below is an example of open-ended problem situated in real world context posed by S16 (see Figure 7).

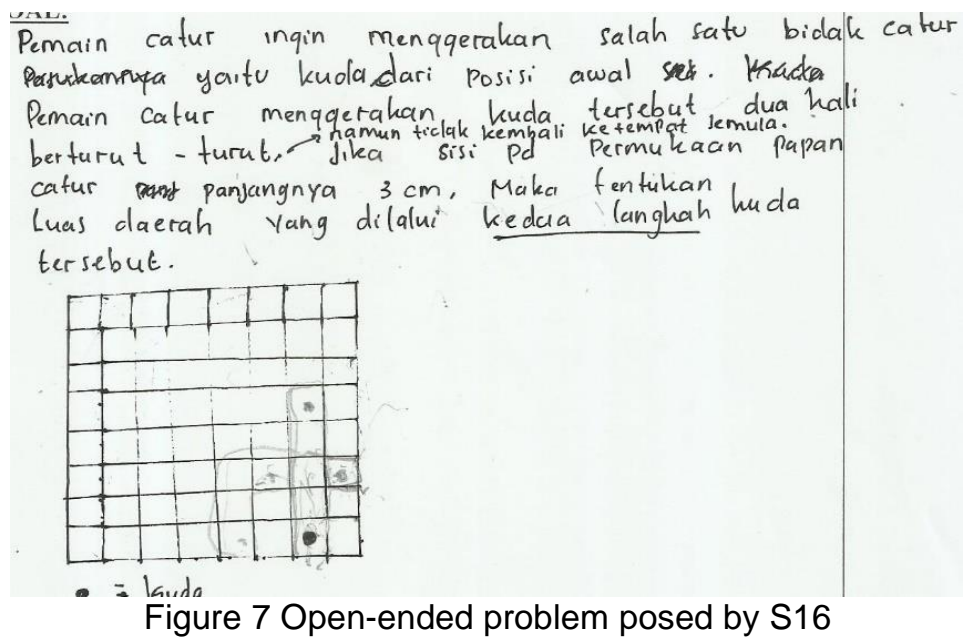

\section{CONCLUSION}

Based on the analysis of prospective teachers' creative thinking abilities in solving and posing open-ended problems, the authors can draw two points of conclusions as follows.

1. Prospective teachers' creative thinking abilities in solving open-ended problems

Students' creative thinking abilities in solving open-ended problems on the topic of quadrilateral fall into four categories, namely very poor, poor, fair and good. In the very poor category, the subject has not been able to solve all the problems. In the poor category, the subjects have been able to complete all the quadrilateral open-ended problems but only able to meet one of the criteria for creative thinking abilities. The prospective teacher with fair category of creative thinking abilities was able to solve all the problems and to meet the flexibility and fluency criteria. Furthermore, the prospective teacher with good category of creative thinking abilities was able to solve all the openended problems flexibly and fluently, and the prospective teacher has shown efforts to achieve the novelty criteria by trying to provide unique solution methods even though those methods are not optimally explored.

2. Prospective teachers' creative thinking abilities in posing open-ended problems

Students' creative thinking abilities in posing open-ended problems on the topic of quadrilateral fall into three categories, namely very poor, poor, and very good. In the very poor category, the prospective teachers have not been able to pose problems that are open-ended. This implies that the students have not been able to meet the three criteria of creative thinking abilities in posing openended problems. The subject with poor category have shown some efforts indicating the flexibility and fluency criteria but the subject those efforts did not optimally executed.

For the prospective teachers with the very good category of creative thinking abilities, they have been able to meet the three criteria for creative thinking, namely fluency, flexibility and novelty 
in designing rectangular open-ended questions. Students are able to design more than one complete quadrilateral open-ended problems, provide more than one correct solutions towards the problems and also build their own ideas to pose the problems. Based on the interview, those students who are very good in posing open-ended problem have learning experience in designing open-ended problem.

The findings above reveal that the prospective teachers' learning experience in solving openended problems greatly affects their abilities to both solve and pose open-ended problems. Therefore, it is very important for educators to provide experience in solving or posing open-ended problems to students. The use of open-ended mathematics problems in learning is believed to be able to improve students' creative thinking abilities.

\section{REFERENCES}

As'ari, A. R., Mahmudi, A., \& Nuerlaelah, E. (2017). Our Prospective Mathematic Teachers Are Not Critical Thinkers Yet. Journal on Mathematics Education, 8(2), 145-156.

Beghetto, R. A. (2017). Lesson unplanning toward transforming routine tasks into non-routine problems. ZDM, 49(7), 987-993.

Bragg, L., \& Nicol, C. (2008). Designing open-ended problems to challenge preservice teachers' views on mathematics and pedagogy. In PME 32: Mathematical ideas: history, education and cognition: Proceedings of the 32nd Conference of the International Group for the Psychology of Mathematics Education (pp. 201-208). International Group for the Psychology of Mathematics Education.

Crespo, S. (2003). Learning to pose mathematical problems: Exploring changes in preservice teachers' practices. Educational Studies in Mathematics, 52(3), 243-270.

Demir, S., \& Sahin, F. (2014). Assessment of open-ended questions directed to prospective science teachers in terms of scientific creativity. Procedia-Social and Behavioral Sciences, 152, 692697.

Ibrahim, I., \& Widodo, S. A. (2020). Advocacy Approach With Open-Ended Problems To Mathematical Creative Thinking Ability. Infinity Journal, 9(1), 93-102.

Kwon, O. N., Park, J. H., \& Park, J. S. (2006). Cultivating divergent thinking in mathematics through an open-ended approach. Asia Pacific Education Review, 7(1), 51-61.

Miles, M. B., \& Huberman, A. M. (1994). Qualitative Data Analysis: An Expanded Sourcebook (2nd ed.). Thousand Oaks, CA: Sage Publications.

Moma, La. 2015. "Pengembangan Instrumen Kemampuan Berpikir Kreatif Matematis untuk Siswa SMP". Jurnal Matematika dan Pendidikan Matematika, 4(1), 27-41.

Oemar, Hamalik. 2001. Teknik Pengukuran dan Evaluasi Pendidikan: Bandung: Mandar Maju.

Schoevers, E. M., Leseman, P. P., Slot, E. M., Bakker, A., Keijzer, R., \& Kroesbergen, E. H. (2019). Promoting pupils' creative thinking in primary school mathematics: A case study. Thinking Skills and Creativity, 31, 323-334.

Silver, E. A. 1994. On Mathematical Problem Posing. For the learning of mathematics, 14(1), 19-28.

Silver, E. A. 1997. Fostering Creativity through Instruction Rich in Mathematical Problem Solving and Problem Posing. The International Journal of Mathematics Education, 29(3), 75-78.

Siswono, Tatag Yuli Eko. 2007. Konstruksi Teoritik Tentang Tingkat Berpikir Kreatif Siswa dalam Matematika. Jurnal Pendidikan, Forum Pendidikan \& IImu Pengetahuan, 2(4), 3.

Siswono, Tatag Yuli Eko. 2016. Proses Berpikir Kreatif Siswa dalam Memecahkan dan Mengajukan Masalah Matematika. Jurnal IImu Pendidikan, 15(1), 61.

Siswono, T. Y. E. (2008). Promoting creavity in learning mathematics using open-ended problems. In The 3 International Conference on Mathematics and Statistics (ICoMS-3) Institut Pertanian Bogor, Indonesia (pp. 5-6).

Sugiyono. 2010. Metode Penelitian Pendidikan (Pendekatan kuantitatif, kualitatif dan R\&D). Bandung: Alfabeta.

Thomas, A., Thorens, G., \& Small, B. 2000. High Order Thinking_It's HOTS. (Online). (http://edl.org./resource library/pdf/feb00PTHOT.pdf, diakses 23 Juni 2020) 